\title{
Records of Risso's dolphin, Grampus griseus, in coastal waters of southern Argentina
}

\author{
Registros del delfín gris, Grampus griseus, en aguas costeras \\ del sur de Argentina
Luciana Riccialdelli ${ }^{1,2}$, Mónica A. Torres ${ }^{2}$, R. Natalie P. Goodall ${ }^{1,2}$, Natalia A. Dellabianca ${ }^{1,2}$, Lida E. Pimper ${ }^{2,3}$, Laura M. Reyes ${ }^{4}$, Alejandro Fernández-Ajó ${ }^{4}$ and Ricardo Bastida ${ }^{5}$

\author{
${ }^{1}$ Centro Austral de Investigaciones Científicas (CADIC), Bernardo Houssay 200, Ushuaia (9410), Tierra del Fuego, Argentina. \\ lriccialdelli@gmail.com \\ ${ }^{2}$ Museo Acatushún de Aves y Mamíferos Marinos Australes, Sarmiento 44, Ushuaia (9410), Tierra del Fuego, Argentina \\ ${ }^{3}$ Departamento de Ecología, Genética y Evolución, Facultad de Ciencias Exactas y Naturales, Universidad de Buenos Aires, \\ Intendente Güiraldes 2160, Ciudad Universitaria, Capital Federal (1427), Argentina \\ ${ }^{4}$ Universidad Nacional de la Patagonia San Juan Bosco, Blvd. Brown 3050, Puerto Madryn (9120), Chubut, Argentina \\ ${ }^{5}$ Universidad Nacional de Mar del Plata, Complejo Universitario, Peña y Funes, Mar del Plata (7600), Argentina
}

\begin{abstract}
We review the records of published and unpublished sightings and strandings for Risso's dolphin (Grampus griseus) in subantarctic waters of the Southwestern South Atlantic Ocean. Based on 59 sighting ( $n=521$ individuals) and 33 stranding records ( $n=88$ individuals), we identified three main areas of Risso's dolphin concentration in Patagonian waters, which have been observed mostly during the austral summer. We were unable to find published or unpublished reports of Risso's dolphin in offshore or over deep-water areas in this region. Future studies covering other potential areas of the species' distribution are important to improve the scarce information known for this dolphin in this area.
\end{abstract}

Key words: Stranding, sightings, Southwestern South Atlantic Ocean

\section{INTRODUCTION}

The subantarctic waters of the Southwestern South Atlantic Ocean are one of the most productive regions of the world (Campagna et al. 2006). These waters are found between two frontal systems, the Subtropical $\left(\sim 40^{\circ} \mathrm{S}\right)$ and the Antarctic $\left(\sim 50-60^{\circ} \mathrm{S}\right)$ Convergences, which provide unique conditions of high nutrient levels and primary production therefore constituting feeding areas for many species of marine mammals (Campagna et al.2006, Bastida et al. 2007, Piola \& Falabella 2009).

Risso's dolphin, Grampus griseus (Cuvier, 1812), is a small cetacean species which inhabits this area (Bastida et al. 2007), although in other parts of the world it is mostly found in temperate and tropical waters (Baird 2008). Due to its offshore habits, few sighting and stranding records have been documented along these coasts (Würsig \& Würsig 1980, Goodall \& Schiavini $1992^{1}$, Reyes 2006, Goodall et al. 2008). While knowledge of other small cetacean and coastal species has increased in recent years (e.g., Commerson's dolphin, Cephalorynchus commersonii; dusky dolphin, Lagenorhynchus obscurus; and Franciscana dolphin, Pontoporia blainvillei; among others), very little is known about the distribution, movements, seasonal occurrence and feeding habits of Risso's dolphin in this region.

Stable isotope analyses suggest that in the Southwestern South Atlantic, Risso's dolphin is mainly an offshore predator (Riccialdelli et al. 2010), as it is in other parts of the world (Shane 1995a, b, Baird 2008, Bearzi et al. 2010). Nevertheless, its isotopic similarities to inshore species such as the Burmeister's porpoise, Phocoena spinipinnis (Riccialdelli et al. 2010), and several published coastal sighting records (Würsig \& Würsig 1980, Reyes 2006), suggest that Risso's dolphin groups

${ }^{1}$ Goodall RNP \& ACM Schiavini. 1992. Varamientos de delfín gris, Grampus griseus, en las costas del extremo sur sudamericano, p. 31. 5ta Reunión de Especialistas en Mamíferos Acuáticos de América del Sur, SOLAMAC, Buenos Aires. 
may move between inshore and offshore habitats, as noted near the Santa Catalina Islands (Shane 1995a, b) and in the NE Pacific Ocean (Leatherwood et al. 1980). According to bone collagen $\delta^{13} \mathrm{C}$ and $\delta^{15} \mathrm{~N}$ values analyzed in Riccialdelli et al. (2010), the Risso's dolphin population in the Southwestern South Atlantic Ocean seems to prefer squid as a prey item, which has been recorded for other regions (Sekiguchi et al. 1992, Cockcroft et al. 1993, Blanco et al. 2006). The movements observed by Shane (1995a, b) near the Santa Catalina Islands in the NE Pacific were related to feeding activities, whereas the ones registered by Leatherwood et al. (1980) appeared to be related to surface temperatures. Therefore, distribution and seasonal movements of the species' main prey (squid) may influence its own distribution and movement patterns in Argentine waters.

The aim of this work is to update sighting and stranding information for Risso's dolphin of Patagonian Argentine waters to clarify the presence of this species in the Southwestern South Atlantic Ocean.

\section{Materials ANd Methods}

The study region was divided into three areas: 1) Area I, north Patagonian waters (Península Valdés area, $\sim 42^{\circ} \mathrm{S}$ ), 2) Area II, central Patagonian waters (Golfo San Jorge area, $\sim 45^{\circ} \mathrm{S}$ ) and 3) Area III, southern Patagonian waters (southern Santa Cruz-Strait of Magellan-Tierra del Fuego area, $\sim 50-54^{\circ} \mathrm{S}$ ) (Fig 1). We compiled and reviewed previously published records and interviewed colleagues for information on Risso's dolphin in Argentine waters as well as reviewing unpublished sighting and stranding events of the species in the study region (Table 1, Fig. 1). Most of the sightings were recorded opportunistically from the shore or small boats, and only sightings reported by Reyes (2006) were made by dedicated surveys at sea. Sighting reports were expressed as the total number of individuals recorded but also as a range of animals sighted. For the latter, we considered the midpoint of each group size estimated. When the midpoint was a noninteger, we used the lower integer.

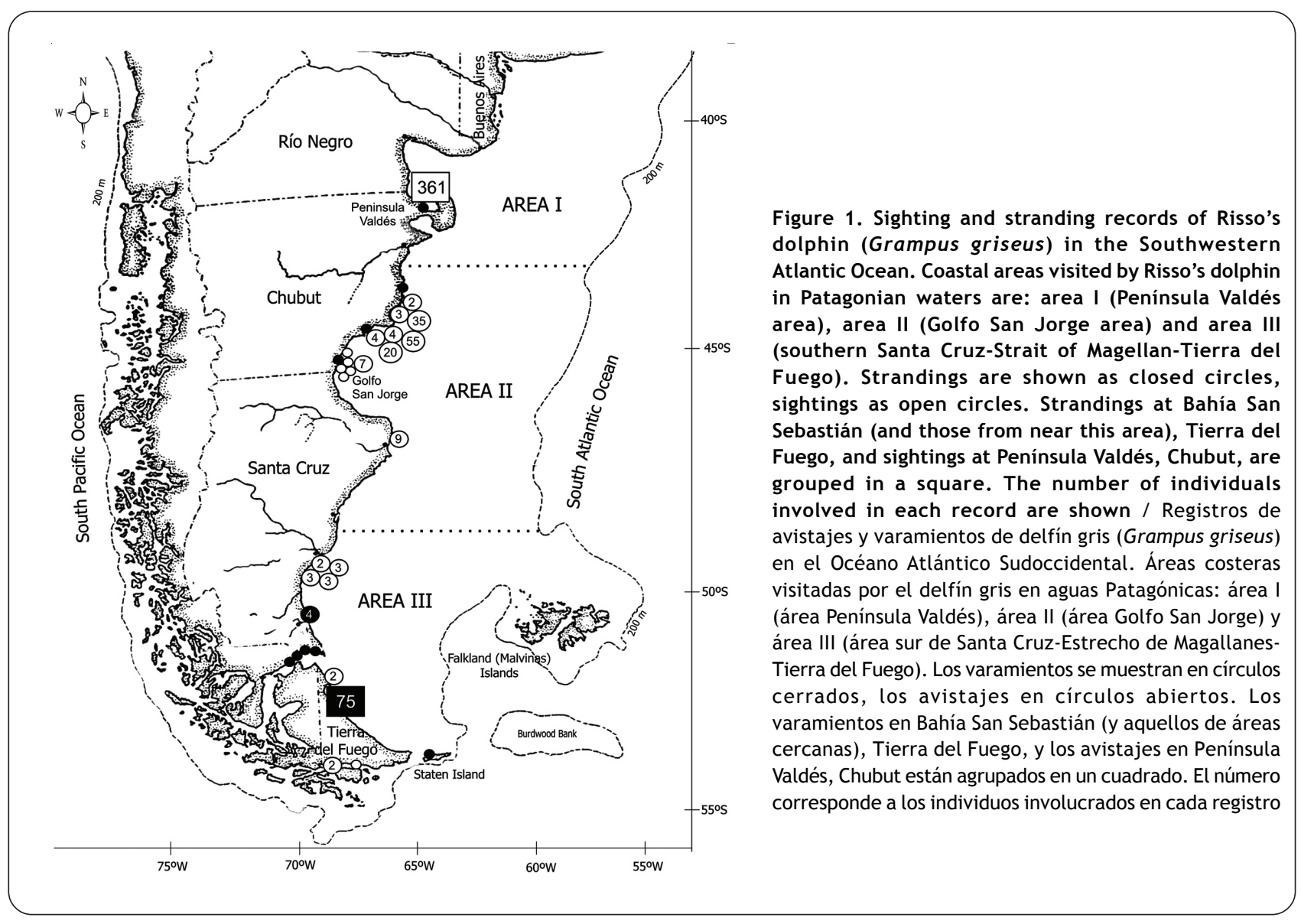


A few stranding records were opportunistic, but most strandings were found during periodic beach surveys by the R. Natalie P. Goodall team from 1974/75 to the present, which primarily took place during austral spring-summer months (October to April). We considered each sighting and stranding event as a record.

\section{Results ANd Discussion}

Fifty-nine sighting and 33 stranding records were available (Table 1, Fig. 1). We found 29 sighting and 16 stranding records which were previously published, and 30 new sighting records and 17 unpublished stranding records.

Sightings were made between the years 1962 and 2006. Of the total definite sightings $(\mathrm{n}=57$, excluding two possible sightings of Risso's dolphin), $67 \%$ corresponded to area I, $24 \%$ and $9 \%$ corresponded to areas II and III, respectively. The number of animals sighted ranged from one to an estimated 100 individuals, with a mean of $9.1( \pm$ 16.2 SD), a mode of 1 and a median group size of 4 . The mean group size of sighted animals is lower than average for the species, $\sim 30$ animals, which can increase to tens or even hundreds in response to abundant food resources (Baird 2008, Bearzi et al. 2010). Most sightings (85.2\%) occurred between October and April ( $\mathrm{n}=46$ records, 377 individuals sighted), with $25.9 \%$ occurring in November, $14.8 \%$ in January and $24.1 \%$ in February. Only $14.8 \%$ of the sightings were in winter months ( $\mathrm{n}=8$ records, 25 individuals sighted) between May and September. Although Risso's dolphin occurs mainly in tropical and temperate waters, we found no sighting records for north of Península Valdés in Argentina, despite numerous marine mammal surveys in the area (Bastida \& Lichtschein 1984, $1986^{2}$, Würsig \& Bastida 1986, Bastida et al. 1992³). We believe this could be related to the lack of their main prey (squid) in these waters or it may indicate that their movements at northern latitudes are mainly in offshore waters.

Due to the lack of dedicated offshore studies we were unable to find any reports of sightings in offshore and deep waters and in the slope edge area of Argentina (Bastida \& Lichtschein 1984, Lovrich 20104, Van
Waerebeek et al. 2010), as is the case for other regions such as Chile, the Azores Archipelago, Gulf of Mexico and the Mediterranean Sea (Baumgartner 1997, Olavarría et al. 2001, Cañadas et al. 2002, Pereira 2008, Bearzi et al. 2010). The lack of records for this species around the Falkland (Malvinas) Islands might be due to the insufficient data available for most species of marine mammal in the area (Otley et al. 2008).

Stranding events were recorded between the years 1960 and 2003. Of the total strandings, $3 \%$ corresponded to area I, $9 \%$ and $88 \%$ corresponded to areas II and III, respectively. The coasts of Area III, where most stranding records (29 records including 84 individuals) of Risso's dolphins occurred, are characterized by high tides, reaching over $10 \mathrm{~m}$ (e.g., Bahía San Sebastián, 53¹8'S$68^{\circ} 16^{\prime} \mathrm{W}$ ) and wide, shallow intertidal zones that provide ideal areas for stranding events (Goodall 1978). In northeastern Tierra del Fuego at least 75 animals were stranded from 1980 to 1999 (Goodall 1989, Goodall et al. 2008, Goodall unpublished data). Some of these events involved a high number of animals being stranded (15 individuals, Table 1). Mass stranding of this species is considered rare (Baird 2008), but there are a few records of mass stranding events in other regions, such as the west coast of South America (Olavarría et al. 2001, GarcíaGodos \& Cardich 2010).

The information about Risso's dolphin presented in this study advances our understanding of the species for this region. However, there are two gaps (areas with no sighting or stranding records) in its occurrence between the three coastal areas studied: one of $\sim 300 \mathrm{~km}$ between Area I and II, and another of $\sim 350 \mathrm{~km}$ between Areas II and III. These gaps may represent the actual absence of the species, or more likely, a limited survey effort carried out in those areas. Off Península Valdés, diving activities and whale watching surveys have taken place earlier than in any other areas (since 1957 and 1980, respectively). For these reasons, cetacean records have always been more numerous than for other areas. In Area II, few research programs have been carried out. In Area III, beach surveys began in 1974-75 for stranded or incidentally caught marine mammals, but sightings of live

2Bastida R \& V Litchschein. 1986. Capturas incidentales de pequeños cetáceos en el área de Mar del Plata (Prov. de Bs. As., Argentina). Actas de la 1ra Reunión de Trabajo de Expertos en Mamíferos Acuáticos de América del Sur, Buenos Aires, Argentina, Junio 1984.

${ }^{3}$ Bastida R, D Rodríguez, V Moreno, A Pérez, J Marcovecchio \& M Gerpe. 1992. Varamientos de pequeños cetáceos durante el período 1984-1988 en el área de Mar del Plata (Provincia de Buenos Aires, Argentina). Anales de la III Reunión de Trabajo de Especialistas en Mamíferos Acuáticos de América del Sur. Montevideo, Uruguay, Julio 1988.

${ }^{4}$ Lovrich G (compiler). 2010. Estudios biológicos en plataforma patagónica austral. Informe de campaña CONCACEN II. p.131. 


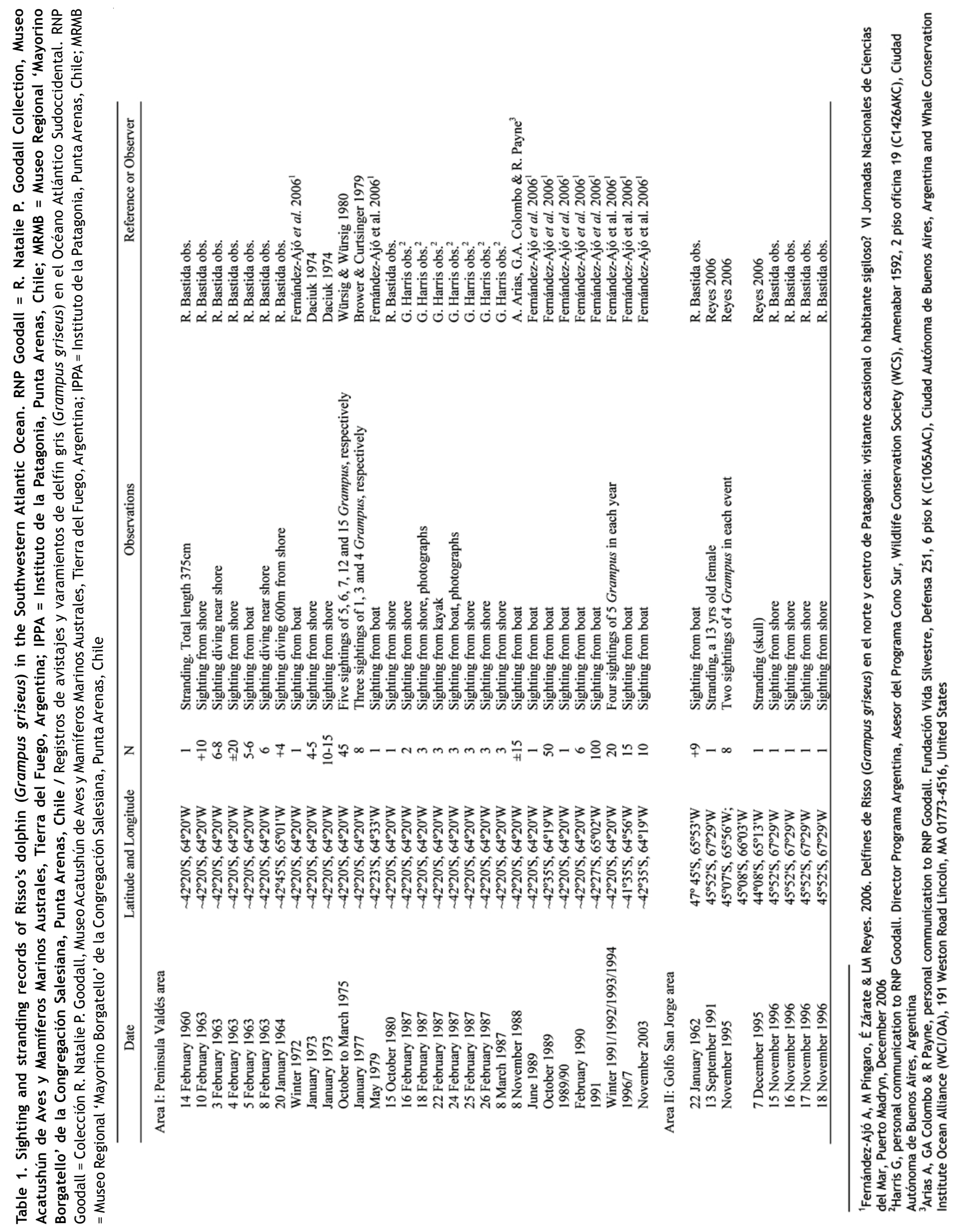




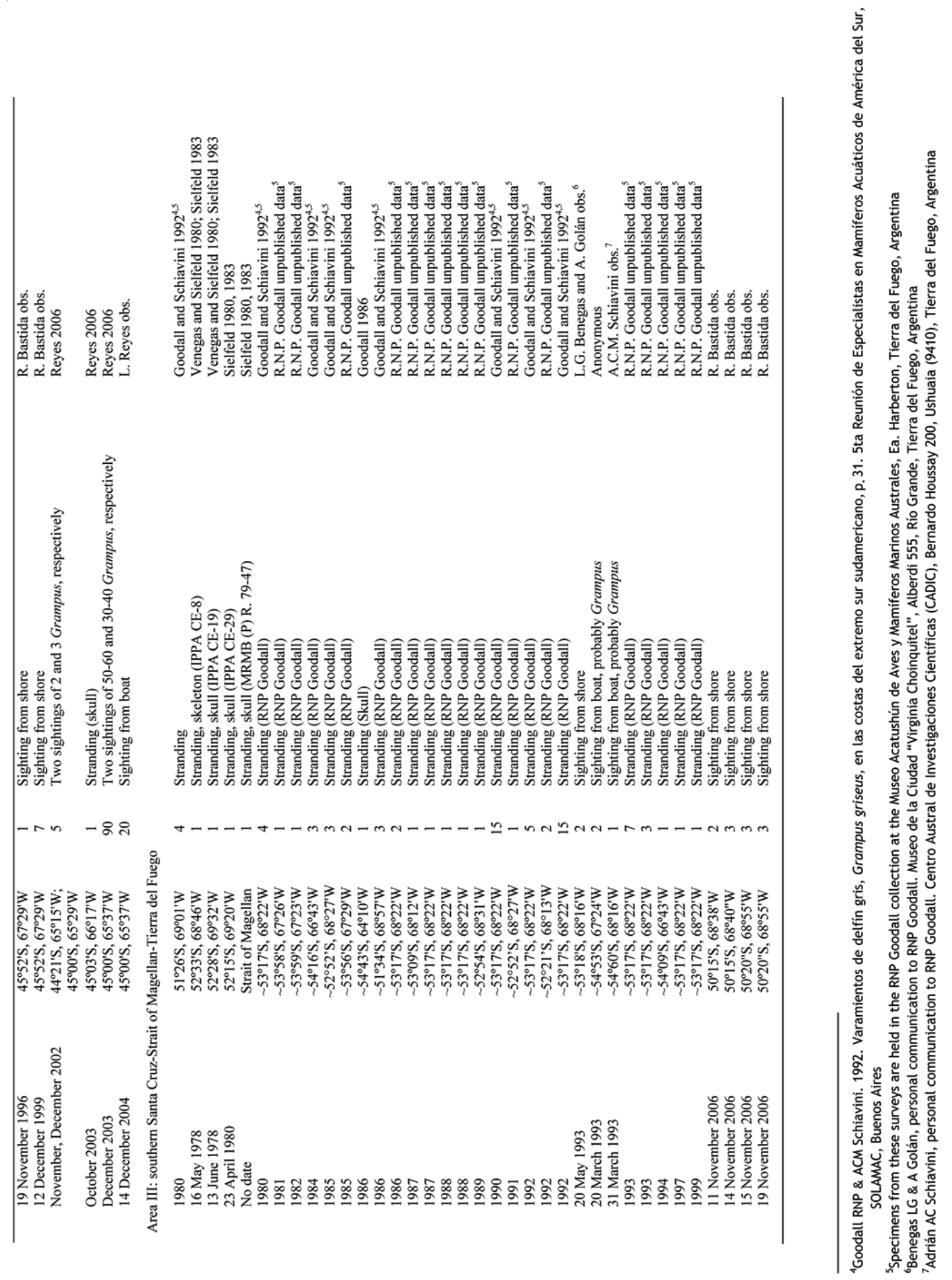


animals were on an opportunistic basis. The isolation of this area, due to long distances from nearby locations, few roads that are in poor condition, and extreme climatic conditions, have resulted in a lack of an organized observation program; nevertheless, there are a large number of stranding records.

The high number of sightings in austral summer months and the low number in winter along the Patagonian coast probably indicates a lack of research effort during winter or that during winter months, Risso's dolphins are in offshore areas or migrate to warmer ocean waters. Also, bad weather conditions and fewer observers may be largely responsible for the lack of sightings in austral fall and winter months. For Area I, sighting records in winter months could indicate the presence of late summer groups (records at the beginning of winter), early summer groups (records at the end of winter months) or the presence of resident groups living in northern Patagonian waters (sightings in mid-winter). The absence of records north of Peninsula Valdés suggests that this species could come in from offshore areas, probably at the southern part of the Province of Buenos Aires. The presence of this species so far south $\left(\sim 52^{\circ}-55^{\circ} \mathrm{S}\right)$, based primarily on stranding records from Area III, could be evidence of short term and seasonal movements of its principal prey. It is also possible that there are long-term fluctuations in the boundaries of its range in response to long-term environmental changes, as suggested by Leatherwood et al. (1980) for Risso's dolphins in the NE Pacific.

Future studies in other potential areas of the Risso's dolphin's distribution, such as the outer continental shelf and slope break, are important to increase the scarce information available on this species in this southern part of the world.

\section{ACKnowledgments}

We gratefully thank G Harris, A Arias, GA Colombo, R Payne, ACM Schiavini, LG Benegas and A Golán for the important unpublished data shared with us. We also thank the collaboration of C Olavarría, M Iñiguez, A Lichter, J Gibbons, C de Haro, E Vermeulen, A Cammareri, J Acevedo, S Dans, Ch Torlaschi, M Píngaro, M Irurueta and JP Seco Pon in responding to our requests for data. C Olavarría provided helpful comments on a previous version of this paper. AC Jakle helped with the English version. This study was supported by Consejo Nacional de Investigaciones Científicas y Técnicas (CONICET) and the Committee for Research and Exploration (CRE) of the
National Geographic Society to RNPG. LMR acknowledges the Rufford Small Grants Foundation and its continued support.

\section{LITERATURE CITED}

Baird RW. 2008. Risso's dolphin. In: Perrin WF, B Würsig \& JGM Thewissen (eds). Encyclopedia of marine mammals, pp. 975-976. Academic Press, San Diego.

Bastida R \& V Lichtschein. 1984. Avistajes de cetáceos realizados por buques balleneros en aguas Argentinas. Revista del Museo Argentino de Ciencias Naturales Bernardino Rivadavia e Instituto Nacional de Investigación de las Ciencias Naturales 22: 211-224.

Bastida R, D Rodríguez, E Secchi \& V da Silva. 2007. Mamíferos acuáticos de Sudamérica y Antártida, 366 pp. Vázquez Mazzini Editores, Buenos Aires.

Baumgartner MF. 1997. The distribution of Risso's dolphin (Grampus griseus) with respect to the physiography of the northern Gulf of Mexico. Marine Mammal Science 13: 614-638.

Bearzi G, RR Reeves, E Remonato, N Pierantonio \& S Airoldi. 2010. Risso's dolphin Grampus griseus in the Mediterranean Sea. Mammalian Biology <doi:10.1016/ j.mambio.2010.06.003>.

Blanco C, MA Raduán \& JA Raga. 2006. Diet of Risso's Dolphin (Grampus griseus) in the western Mediterranean Sea. Scientia Marina 70: 407-411.

Brower K \& WR Curtsinger. 1979. Wake of the whale, 160 pp. Friends of the Earth, EP Dutton, New York.

Campagna C, C Verona \& V Falabella. 2006. Situación ambiental en la ecoregión del Mar Argentino. In: Brown A, U Martínez-Ortiz, M Acerbi \& J Corcuera (eds). La situación ambiental argentina 2005, pp 323-336. Fundación Vida Silvestre Argentina, Buenos Aires.

Cañadas A, R Sagarminaga \& S García-Tiscar. 2002. Cetacean distribution related with depth and slope in the Mediterranean waters off southern Spain. Deep Sea Research 49: 2053-2073.

Cockcroft VG, SL Haschick \& NTW Klages. 1993. The diet of Risso's dolphin, Grampus griseus (Cuvier, 1812), from the east coast of South Africa. Zeitschrift fur Säugetierkunde 58: 286-293.

Daciuk J. 1974. Notas faunísticas y bioecológicas de Península Valdés y Patagonia. XII. Mamíferos colectados y observados en la Península Valdés y zona litoral de los Golfos San José y Nuevo (Provincia de Chubut, República Argentina). Physis 33(86): 23-39.

García-Godos I \& C Cardich. 2010. First mass stranding of Risso's dolphins (Grampus griseus) in Peru and its destiny as food and bait. Marine Biodiversity Records, JMBA 3: 1-4.

Goodall RNP. 1978. Report on the small cetaceans stranded on the coast of Tierra del Fuego. The Scientific Reports of the Whales Research Institute, Tokyo 30:197-230. 
Goodall RNP. 1986. Second cetacean survey of eastern Tierra del Fuego and Isla de los Estados. Antarctic Journal [of the United States] 21: 210-213.

Goodall RNP. 1989. The lost whales of Tierra del Fuego. Oceanus 32: 89-95.

Goodall RNP, LG Benegas, CC Boy, N Dellabianca, L Pimper \& L Riccialdelli. 2008. Review of small cetaceans stranded or incidentally captured on the coast of Tierra del Fuego, Argentina, over 33 years. Paper SC/60/SM21 presented to the Scientific Committee, International Whaling Commission, June 2008, 14 pp. [on line] $<$ www.iwcoffice.org $>$.

Leatherwood S, WF Perrin, VL Kirby, CL Hubbs \& ME Dahlheim. 1980. Distribution and movements of Risso's dolphin, Grampus griseus, in the eastern North Pacific. Fishery Bulletin 77: 951-963.

Olavarría C, A Aguayo-Lobo \& R Bernal. 2001. Distribution of Risso's dolphin (Grampus griseus, Cuvier 1812) in Chilean waters. Revista de Biología Marina y Oceanografía 36: 111-116.

Otley H, G Munro, A Clausen \& B Ingham. 2008. Falkland Islands State of the Environment Report 2008, 288 pp. Falkland Islands Government and Falklands Conservation, Stanley.

Pereira JNDSG. 2008. Field notes on Risso's dolphin (Grampus griseus) distribution, social ecology, behaviour, and occurrence in the Azores. Aquatic Mammals 34: 426435.

Piola AR \& V Falabella. 2009. El Mar patagónico. In: Falabella V, C Campagna \& J Croxall (eds). Atlas del Mar Patagónico: Especies y espacios, pp. 56-75. Widlife Conservation Society and Birdlife International, Buenos Aires.

Reyes L. 2006. Cetaceans of central Patagonia, Argentina. Aquatic Mammals 32: 20-30.
Riccialdelli L, SD Newsome, ML Fogel \& RNP Goodall. 2010. Isotopic assessment of prey and habitat preferences of a cetacean community in the southwestern South Atlantic Ocean. Marine Ecology Progress Series 418: 235-248.

Sekiguchi K, NTW Klages \& PB Best. 1992. Comparative analysis of the diets of smaller odontocete cetaceans along the coast of Southern Africa. South African Journal of Marine Science 12: 843-861.

Shane SH. 1995a. Relationship between pilot whales and Risso's dolphins at Santa Catalina Island, California, USA. Marine Ecology Progress Series 123: 5-11.

Shane SH. 1995b. Behavior patterns of pilot whales and Risso's dolphins off Santa Catalina Island, California. Aquatic Mammals 21: 195-197.

Sielfeld W. 1980. Mamíferos marinos en colecciones y museos de Chile. Anales del Instituto de la Patagonia 11: 273-280.

Sielfeld W. 1983. Mamíferos marinos de Chile, 199 pp. Ediciones de la Universidad de Chile, Santiago.

Van Waerebeek K, R Leaper, AN Baker, V Papastavrou, D Thiele, K Dindaly, G, Donovan \& P Ensor. 2010. Odontocetes of the Southern Ocean Sanctuary. Journal of Cetacean Research and Management 11: 315-346.

Venegas C \& W Sielfeld. 1978. Registros de Mesoplodon layardii y otros cetáceos en Magallanes. Anales del Instituto de la Patagonia 9: 171-177.

Würsig B \& R Bastida. 1986. Long-range movement and individual associations of two dusky dolphins (Lagenorhynchus obscurus) off Argentina. Journal of Mammalogy 67: 773-774.

Würsig B \& M Würsig. 1980. Behavior and ecology of the dusky dolphin, Lagenorhynchus obscurus, in the South Atlantic. Fishery Bulletin 77: 871-890.

Received 30 March 2011 and accepted 15 September 2011 